\title{
Early Detection of Failed Bank Through Analysis of Financial Ratios and Bank Shareholders Ratios Using Data Mining For Rural Banks
}

\author{
H M Agista ${ }^{1}$, E Budiarto ${ }^{1, *}$, and B Mahawan ${ }^{1}$ \\ ${ }^{1}$ Business Informatics, Swiss German University, Tangerang 15143, Indonesia \\ ${ }^{*}$ Corresponding author: eka.budiarto@sgu.ac.id
}

\begin{abstract}
This study aims to determine the effect of 8 bank financial ratios such as BOPO (operational efficiency ratio), CAR (Capital Adequacy Ratio), NPL (Non Performing Loan), ROA (Return On Assets), CR (Cash Ratio), KAP (quality of productive assets), PPAP (provision for loan losses) and LDR (Loan Deposit Ratio) and another ratio, namely Bank's Shareholder ratio towards bank predictions whether a rural bank will be declared as failed bank or not. Eight financial ratios and another ratio that comparing BOD and BOC to Bank's Shareholders can be obtained from quarterly rural bank's financial reports that have been published on the IFSA website from 2014 until 2018. The data in this research is approximately 1000 rural banks for training dataset. The method to predict rural bank become failed bank is data mining. The training dataset used is an imbalanced dataset. In order to be balanced, the SMOTE method is used. The balance dataset was then analyzed with the data mining process. The data mining methods used are KNN and Naïve Bayes, both are classification method.
\end{abstract}

\section{Introduction}

Deposit insurance is being implemented in many countries to protect bank depositors, in full or in part, from losses caused by a bank's inability to pay its debts when due. Deposit insurance systems are one component that promotes financial stability. One of the countries that have deposit insurance corporation is in Indonesia, called IDIC (Indonesia Deposit Insurance Corporation) or Lembaga Penjamin Simpanan in Bahasa Indonesia. One of the IDIC duties is to handle a failed bank (Indonesia Deposit Insurance Corporation, 2018a).

Before becoming a failed bank, that bank would become under special surveillance. IDIC received some notices on under special surveillance bank from IFSA (Indonesia Financial Services Authority) or Otoritas Jasa Keuangan in Bahasa Indonesia. IDIC, together with IFSA, examined those banks and conduct assessment on their financial condition to asses that bank will be a failed bank or not. If become a failed bank, IDIC must handle the failed bank with several methods of resolution bank (Indonesia Deposit Insurance Corporation, 2019). It would be better if IDIC can predict which bank will be assigned as a failed bank so that IDIC can early prepare its resources and become more careful planning to deal with the bank.

To make an early detection or prediction which bank will become a failed bank, this research will use financial ratios and bank shareholder ratio. This study raises the topic of whether there is a relationship between bank financial ratios and bank shareholders to predict which bank will become a failed bank, especially for rural banks. Rural banks are the main focus because there are 91 rural banks out of the total liquidated banks until the end of 2018. (Indonesia Deposit Insurance Corporation, 2018b)

The data source that will be used is the rural bank's publication reports published in the IFSA's website and failed bank status for the label or class (Indonesia Financial Services Authority, 2018)(Indonesia Deposit Insurance Corporation, 2018b). The scope of the study is limited to the rural bank. The data is obtained from rural bank quarterly publication reports with restrictions from the period 2017 to 2018 and rural bank data that are stated as a failed bank. The data collected is used to create data mining models. The model formed will be used to make predictions to determine whether a rural bank will be declared as a failed bank or not. This research is different from previous research that can be explained in Table 1. 
Table 1. Compare with Previous Researches

\begin{tabular}{|c|c|c|c|c|c|}
\hline $\begin{array}{l}\text { Author and } \\
\text { References }\end{array}$ & $\begin{array}{l}\text { Ni Putu Ayu Lisna } \\
\text { Purnamandari and } \\
\text { I Dewa Nyoman } \\
\text { Badera } \\
\text { (Purnamandari and } \\
\text { Badera, 2015) }\end{array}$ & $\begin{array}{l}\text { Luciana Spica } \\
\text { Almilia and } \\
\text { Winny } \\
\text { Herdinigtyas } \\
\text { (Almilia and } \\
\text { Herdinigtyas, } \\
\text { 2005) }\end{array}$ & $\begin{array}{l}\text { Roberto } \\
\text { Christian } \\
\text { Widiharto } \\
\text { (Widiharto, } \\
\text { 2008) }\end{array}$ & $\begin{array}{l}\text { Reny Sri Harjanti } \\
\text { (Harjanti, 2011) }\end{array}$ & This Research \\
\hline Bank & 22 Banks & 24 Banks & $\begin{array}{ll}201 & \text { Rural } \\
\text { Banks } & \end{array}$ & 27 Banks & $\begin{array}{l}\text { About } 1000 \\
\text { Rural Banks } \\
\text { for creating the } \\
\text { dataset }\end{array}$ \\
\hline $\begin{array}{l}\text { Financial } \\
\text { Reports } \\
\text { Period }\end{array}$ & 2009-2013 & $2000-2002$ & $2002-2006$ & 2004-2008 & 2014-2018 \\
\hline $\begin{array}{l}\text { Financial } \\
\text { Ratios }\end{array}$ & CAR, BOPO, NPL & $\begin{array}{l}\text { CAR, BOPO, } \\
\text { NPL, ATTM, } \\
\text { APB, PPAP, } \\
\text { PPAP } \\
\text { Fulfillment, } \\
\text { ROA, ROE, } \\
\text { NIM, LDR }\end{array}$ & $\begin{array}{l}\text { CAR, BOPO, } \\
\text { APB, PPAP, } \\
\text { Profit Margin, } \\
\text { ROA, LDR }\end{array}$ & $\begin{array}{l}\text { CAR, BOPO, } \\
\text { NPL, ROA, } \\
\text { ROE, NIM, LDR }\end{array}$ & $\begin{array}{lr}\text { CAR, } & \text { BOPO, } \\
\text { NPL, } & \text { KAP, } \\
\text { LDR, } & \text { PPAP, } \\
\text { ROA, } & \text { Cash } \\
\text { Ratio } & \end{array}$ \\
\hline $\begin{array}{l}\text { Another } \\
\text { Parameter }\end{array}$ & Bank Size & - & - & - & $\begin{array}{l}\text { Compare } \\
\text { directors } \\
\text { and } \\
\text { commissioners } \\
\text { with } \\
\text { shareholders } \\
\text { name }\end{array}$ \\
\hline Method & $\begin{array}{l}\text { Regression } \\
\text { Analysis }\end{array}$ & $\begin{array}{l}\text { Logistic } \\
\text { Regression }\end{array}$ & $\begin{array}{l}\text { Logistic } \\
\text { Regression }\end{array}$ & $\begin{array}{l}\text { Logistic } \\
\text { Regression }\end{array}$ & $\begin{array}{l}\text { Classification } \\
\text { using } \\
\text { KNN and Naïve } \\
\text { Bayes }\end{array}$ \\
\hline Prediction & Bankruptcy & Bankruptcy & Bankruptcy & Bankruptcy & Bankruptcy \\
\hline
\end{tabular}

\section{Materials and Methods}

\subsection{Dataset}

Data consisting of 8 bank financial ratios and 1 shareholder ratio compared to directors and commissioners will be used as parameters or attributes. Whereas bank data is declared as a failed bank, will be a label or class. The number of records for this training dataset is 938 which consists of 920 stated as normal banks in 2017 and 18 declared failed banks in 2015 until 2017.

The training dataset which was formed from 9 attributes and 1 class was prepared from financial report data from 2014 to 2017. Each year has 4 reporting periods, namely Quarter 1 (Q1), Quarter 2 (Q2), Quarter $3(\mathrm{Q} 3)$ and Quarter $4(\mathrm{Q} 4)$. Attributes that will be used is last 4 report period $\times 9$ attributes $=36$ attributes. The explanation of the reporting period of training dataset can be seen in Table 2.

Table 2 Time Period of Training Dataset

\begin{tabular}{|c|c|c|c|c|c|c|}
\hline Bank Name & $\begin{array}{l}\text { Liquidation } \\
\text { M/D/YYYY }\end{array}$ & Date & $\begin{array}{l}\text { Start } \\
\text { Period }\end{array}$ & Report & $\begin{array}{l}\text { End } \\
\text { Period }\end{array}$ & Report \\
\hline PT. BPR Carano Nagari & $7 / 10 / 2015$ & & Q4 2014 & & Q3 2015 & \\
\hline PT. BPR Cita Makmur Lestari & $12 / 18 / 2015$ & & Q4 2014 & & Q3 2015 & \\
\hline PT. BPR Agra Arthaka Mulya & $1 / 14 / 2016$ & & Q1 2015 & & Q4 2015 & \\
\hline
\end{tabular}




\begin{tabular}{|c|c|c|c|}
\hline Bank Name & $\begin{array}{l}\text { Liquidation } \\
\text { M/D/YYYY }\end{array}$ & $\begin{array}{l}\text { Start } \\
\text { Period }\end{array}$ & $\begin{array}{l}\text { End } \\
\text { Period }\end{array}$ \\
\hline PT BPR Mitra Bunda Mandiri & $1 / 22 / 2016$ & Q1 2015 & Q4 2015 \\
\hline PT. BPR Dana Niaga Mandiri & $4 / 13 / 2016$ & Q2 2015 & Q1 2016 \\
\hline PT. BPR Kudamas Sentosa & $4 / 29 / 2016$ & Q2 2015 & Q1 2016 \\
\hline PT. BPR Mustika Utama Kolaka & $6 / 20 / 2016$ & Q2 2015 & Q1 2016 \\
\hline PT. BPR Artha Dharma & $8 / 15 / 2016$ & Q3 2015 & Q2 2016 \\
\hline PT. BPR Multi Artha Mas Sejahtera & $12 / 20 / 2016$ & Q4 2015 & Q3 2016 \\
\hline PT. BPR Nova Trijaya & $1 / 20 / 2017$ & Q1 2016 & Q4 2016 \\
\hline PT. BPR Dhasatra Artha Sempurna & $2 / 3 / 2017$ & Q1 2016 & Q4 2016 \\
\hline PT. BPR Nusa Galang Makmur & $3 / 7 / 2017$ & Q1 2016 & Q4 2016 \\
\hline PT. BPR Indomitra Mega Kapital & $6 / 15 / 2017$ & Q2 2016 & Q1 2017 \\
\hline PT. BPR Tri Harta Indah & $6 / 15 / 2017$ & Q2 2016 & Q1 2017 \\
\hline PT. BPR Sisibahari Dana & $9 / 5 / 2017$ & Q3 2016 & Q2 2017 \\
\hline PT. BPR KS Bali Agung Sedana & $11 / 3 / 2017$ & Q4 2016 & Q3 2017 \\
\hline PT. BPR LPN Kampung Manggis & $11 / 29 / 2017$ & Q4 2016 & Q3 2017 \\
\hline PT. BPR Sinar Baru Perkasa & $12 / 6 / 2017$ & Q2 2016 & Q1 2017 \\
\hline Other Rural Bank (Normal Bank) & $<\mathrm{NONE}>$ & Q1 2017 & Q4 2017 \\
\hline
\end{tabular}

The distribution of training dataset categorized as imbalanced dataset because the ratio of normal bank and failed bank is $920: 18$. There are several options to handle imbalance dataset such as collecting more data to get more example of minor class, changing the performance metric (not just using accuracy for measurement), resampling dataset like over-sampling or under-sampling and generate synthetic samples like using the most popular algorithm like SMOTE (Synthetic Minority Over-sampling Technique) (Brownlee, 2015) (Chawla, N.V., Bowyer, K.W., Hall, L.O., 2002).

Facing this imbalance dataset, this research will choose SMOTE using WEKA to balance the training dataset. Using SMOTE, the imbalance training dataset from 938 records become 1838 records. The ratio of normal bank and the failed bank is 920:918. The final training dataset consist of 36 attribute and 1 class these are BOPO_1, CR_1, KAP_1, KPMM_1, LDR_1, NPL_1, PPAP_1, PS_1, ROA_1, BOPO_2, CR_2, KAP_2, KPMM 2, LDR_2, NPL_2, PPAP_2, PS_2, ROA_2, BOPO_3, CR_3, KAP_3, KPMM_3, LDR_3, NPL_3, PPAP_3, PS_3, ROA_3, BOPO_4, CR_4, KAP_4, KPMM_4, LDR_4, NPL_4, PPAP_4, PS_4, ROA_4, and Liquidation.

The balance training dataset then will be processed using data mining classification methods namely KNN and Naive Bayes with validation using 10 cross-validation to get the accuracy results. The model formed from the data mining process will be used to test the dataset by taking a sample of 14 rural banks with 7 banks declared as failed, and 7 banks declared normal. The reporting period used is starting from 2017 until 2018. This distribution of testing dataset can be seen in Table 3.

Table 3 Time Period of Testing Dataset

\begin{tabular}{|c|c|c|c|}
\hline Bank Name & $\begin{array}{l}\text { Liquidation } \\
\text { M/D/YYYY }\end{array}$ & $\begin{array}{l}\text { Start } \\
\text { Period }\end{array}$ & $\begin{array}{l}\text { End } \\
\text { Period }\end{array}$ \\
\hline PT. BPR Bina Dian Citra & $4 / 4 / 2018$ & Q2 2017 & Q1 2018 \\
\hline PT. BPR Akarumi & $4 / 25 / 2018$ & Q2 2017 & Q1 2018 \\
\hline PT. BPR Budisetia & $5 / 25 / 2018$ & Q2 2017 & Q1 2018 \\
\hline PT. BPR Mega Karsa Mandiri & $6 / 5 / 2018$ & Q2 2017 & Q1 2018 \\
\hline PT. BPR Sambas Arta & $7 / 12 / 2018$ & Q3 2017 & Q2 2018 \\
\hline PT. BPR Sinarenam Permai Jatiasih & $11 / 8 / 2018$ & Q4 2017 & Q3 2018 \\
\hline PT. BPR Bintang Ekonomi Sejahtera & $11 / 22 / 2018$ & Q4 2017 & Q3 2018 \\
\hline Other Rural Bank (Normal Bank) & $<\mathrm{NONE}>$ & Q4 2017 & Q3 2018 \\
\hline
\end{tabular}


The accuracy of the prediction results using the data mining method using the testing dataset can be analyzed by comparing whether the reality and predictions are the same or not.

\subsection{Data Mining}

Financial ratio data and bank management's name can be used as a dataset to predict which banks will become failed bank by using the data mining method. Data mining is the way toward finding insightful, interesting and new patterns, as well as descriptive, understandable and predictive models from expansive scale data. Data mining includes some tasks like anomaly detection, classification, regression, association rule learning, summarization and clustering (Saurkar et al., 2014). The method of data mining to be used in this research is classification. A Classification consists of examining the features of a new object and assigning the new object from a set of classes that have been determined. Classification is portrayed by well-defined classes, and a training set comprising of reclassified examples. The task is to assemble a model that can be connected to data that isn't classified to classify it. Because the data that will be used in this research has a well-defined class, KNN and Naïve Bayes (Irfan et al., 2018) will be chosen for this research as one of the classification methods for predicting failed bank.

\section{Results and Discussion}

\subsection{Evaluation}

The data mining process will be evaluated and interpreted based on a certain size that can be seen in Table 4.

Table 4 Evaluation Item

\begin{tabular}{|l|l|}
\hline \multicolumn{1}{|c|}{ Evaluation } & \multicolumn{1}{c|}{ Calculation } \\
\hline TP (True Positive) & The number of true-positive predictions \\
\hline TN (True Negative) & The number of true-negative predictions \\
\hline FP (False Positive) & The number of false-positive predictions \\
\hline FN (False Negative) & The number of false-negative predictions \\
\hline accuracy (ACC) & $($ Correct predictions $) /($ Number of Examples $)=(\mathrm{TP}+\mathrm{TN}) /(\mathrm{TP}+\mathrm{FP}+\mathrm{FN}+$ \\
& $\mathrm{TN})$ \\
\hline Precision & $($ True positive predictions $) /($ All positive predictions $)=\mathrm{TP} /(\mathrm{TP}+\mathrm{FP})$ \\
\hline sensitivity (SN) or recall & $($ True positive predictions $) /($ Number of positive Examples $)=\mathrm{TP} /(\mathrm{TP}+\mathrm{FN})$ \\
\hline F1 score & 2 (precision * recall) $/($ precision + recall) $=2 \mathrm{TP} /(2 \mathrm{TP}+\mathrm{FP}+\mathrm{FN})$ \\
\hline
\end{tabular}

Facing imbalanced dataset, performance metrics that should be used to evaluate beside Accuracy (ACC) is Precision or Positive Predictive Value (PPV), Recall (REC) or Sensitivity (SN) and F1-Score. (Brownlee, 2015)(Paul, 2018)(He and Garcia, 2009)

ACC is calculated as the number of correct predictions divided by the data set's total number. The best accuracy is 1.0, the worst accuracy is 0.0 . PPV is calculated as the number of positive predictions divided by the total number of positive class values predicted. PPV can be thought of as a measure of a classifier's exactness. A low PPV can also indicate a large number of False Positives. SN is calculated as the number of correct positive predictions divided by the positive total number. The best sensitivity is 1.0 , the worst sensitivity is 0.0 . SN can be thought of as a measure of a classifier's completeness. A low SN indicates many False Negatives. F1-Score is the harmonic average of the PPV and SN, calculated as $2 \times((\mathrm{PPV} \times \mathrm{SN}) /(\mathrm{PPV}+\mathrm{SN}))$. A confusion matrix is formed from the four outcomes produced as a result of binary classification.

This research will utilize one of the data mining apparatuses called RapidMiner. RapidMiner can be used as a tool, to do regression, classification and clustering procedures as well as dimension reduction and parameter optimization. These methods can be utilized for different application domains, for example, text, picture, and time series analysis (Land and Fischer, 2012). Table 6 is a confusion matrix 
using KNN method and Table 5 is a confusion matrix using Naïve Bayes that was produced by Rapidminer.

Table 5 Confusion Matrix of Naive Bayes using 10 Cross-Validation

\begin{tabular}{|l|l|l|}
\hline & True NO & True YES \\
\hline Prediction NO & $848(\mathrm{TN})$ & $6(\mathrm{FN})$ \\
\hline Prediction YES & $72(\mathrm{FP})$ & $912(\mathrm{TP})$ \\
\hline
\end{tabular}

Table 6 Confusion Matrix of KNN using 10 Cross-Validation

\begin{tabular}{|l|l|l|}
\hline & True NO & True YES \\
\hline Prediction NO & $900(\mathrm{TN})$ & $1(\mathrm{FN})$ \\
\hline Prediction YES & $20(\mathrm{FP})$ & $917(\mathrm{TP})$ \\
\hline
\end{tabular}

The performance result of using KNN and Naïve Bayes can be seen in Table 7.

Table 7 Training Dataset Performance Result

\begin{tabular}{|l|l|l|}
\hline \multicolumn{1}{|c|}{ Measures } & \multicolumn{1}{|c|}{ KNN (\%) } & Naïve Bayes (\%) \\
\hline Accuracy & 98.86 & 95.76 \\
\hline Sensitivity & 97.83 & 99.35 \\
\hline Precision & 99.87 & 92.68 \\
\hline F1-Score & 98.87 & 95.90 \\
\hline
\end{tabular}

\subsection{Prediction}

From the experiment above, it shows both of the classification methods produce more than $90 \%$ accuracy. Both are good to be used to predict which bank will be declared as a failed bank. Using KNN and Naïve Bayes, this research will apply that model using a new dataset or testing dataset. Table 9 is a confusion matrix using KNN method and Table 8 is a confusion matrix using Naïve Bayes that was produced by Rapidminer.

Table 8 Confusion Matrix of Naive Bayes on Testing Dataset

\begin{tabular}{|l|l|l|}
\hline & True NO & True YES \\
\hline Prediction NO & $7(\mathrm{TN})$ & $1(\mathrm{FN})$ \\
\hline Prediction YES & $0(\mathrm{FP})$ & $6(\mathrm{TP})$ \\
\hline
\end{tabular}

Table 9 Confusion Matrix of KNN on Testing Dataset

\begin{tabular}{|l|l|l|}
\hline & True NO & True YES \\
\hline Prediction NO & $7(\mathrm{TN})$ & $2(\mathrm{FN})$ \\
\hline Prediction YES & $0(\mathrm{FP})$ & $5(\mathrm{TP})$ \\
\hline
\end{tabular}

The performance result of using KNN and Naïve Bayes can be seen in Table 10.

Table 10 Performance Result on Testing Dataset

\begin{tabular}{|l|l|l|}
\hline \multicolumn{1}{|c|}{ Measures } & \multicolumn{1}{|c|}{ KNN (\%) } & \multicolumn{1}{c|}{ Naïve Bayes (\%) } \\
\hline Accuracy & 85.71 & 92.86 \\
\hline Sensitivity & 71.43 & 85.71 \\
\hline Precision & 100 & 100 \\
\hline F1-Score & 83.33 & 92.31 \\
\hline
\end{tabular}

\section{Conclusion}

\subsection{Conclusion}

This research has shown that data mining can be used to get the pattern and predict the bank stated as a failed bank using financial ratios and shareholders ratios data. This research has been done by using KNN and Naïve Bayes on the financial ratios and shareholder ratios data. 
When using 10 Cross-Validation on training dataset about 1838 records, KNN is better than Naïve Bayes because it has 3 higher performance value than Naïve Bayes from 4 selected measurement (accuracy, sensitivity, precision, and f1-score). For prediction using testing dataset about 14 records, it turns out that Naive Bayes is better than KNN because it has 4 higher value than KNN from 4 selected measurement.

Moreover, Naïve Bayes is better in determining Sensitivity (SN). The SN score in the testing dataset shows that KNN has a lower score than Naïve Bayes. A low SN indicates it has many False Negatives (FN). FN score means that the actual data is rural bank declared as a failed bank, but the prediction shows that rural bank is a normal bank and this is a big concern for this case.

By using Naïve Bayes and KNN this research shows that both of them can be used to predict which bank will become a failed bank and normal bank. This can be seen in the experiments using 14 records in the testing dataset. Using Naïve Bayes can predict 6 banks will become failed and in fact, they fail. While 7 banks are still being a normal bank and in fact, they normal. Using KNN can predict 5 banks will become failed and in fact, they fail. While 7 banks are still being a normal bank and in fact, they normal.

From the results of the study, it can be concluded that processing financial ratios and shareholders ratios data using data mining methods such as Naïve Bayes and KNN can be used as an early detection to predict that any banks will become failed bank.

\subsection{Future Works}

This research can be further developed using data mining with other methods and doing research using monthly financial reports data if being published by IFSA in the future so that the report time span is not too far. Also, it can be further developed using several techniques such as under-sampling and oversampling to handle imbalanced dataset. This research may be applied in any other DIC (Deposit Insurance Corporation) that have similar characteristics, namely those that have many rural banks as IDIC has.

\section{References}

Almilia, S. L. and Herdinigtyas, W. (2005) 'Analisis Rasio Camel Terhadap Prediksi Kondisi Bermasalah Pada Lembaga Perbankan Perioda 2000-2002', Jurnal Akuntansi dan Keuangan, 7(2), pp. 131-147. doi: 10.9744/jak.7.2.pp. 131-147.

Brownlee, J. (2015) 8 Tactics to Combat Imbalanced Classes in Your Machine Learning Dataset. Available at: https://machinelearningmastery.com/tactics-to-combat-imbalanced-classes-inyour-machine-learning-dataset/ (Accessed: 1 December 2018).

Chawla, N.V., Bowyer, K.W., Hall, L.O., K. W. P. (2002) 'SMOTE: Synthetic Minority Over-Sampling Technique. Journal of Artificial Intelligence Research', Journal of Artificial Intelligence Research, 16, pp. 321-357. doi: 10.1613/jair.953.

Harjanti, R. (2011) 'Analisis Pengaruh Rasio Keuangan Terhadap Prediksi Kebangkrutan Bank', Bachelor thesis, Faculty of Economy, Universitas Diponegoro. Available at http://eprints.undip.ac.id/29313/1/Skripsi015.pdf

He, H. and Garcia, E. A. (2009) 'Learning from Imbalanced Data', IEEE Transactions on Knowledge and Data Engineering, 21(9), pp. 1263-1284.

Indonesia Deposit Insurance Corporation (2018a) Functions, Duties \& Authorities of IDIC. Available at: https://lps.go.id/web/guest/fungsi-tugas-wewenang (Accessed: 1 December 2018).

Indonesia Deposit Insurance Corporation (2018b) Liquidated Bank. Available at: https://lps.go.id/web/guest/bank-yang-dilikuidasi (Accessed: 31 December 2018).

Indonesia Deposit Insurance Corporation (2019) Mechanism of Bank Rescue. Available at: https://lps.go.id/web/guest/mekanisme-resolusi-bank (Accessed: 2 February 2019).

Indonesia Financial Services Authority (2018) Laporan Publikasi BPR Konvensional. Available at: https://cfs.ojk.go.id/CFS (Accessed: 10 October 2018).

Irfan, M. et al. (2018) 'Comparison of Naive Bayes and K-Nearest Neighbor methods to predict divorce issues', IOP Conference Series: Materials Science and Engineering, 434(1). doi: 10.1088/1757899X/434/1/012047. 
Land, S. and Fischer, S. (2012) 'RapidMiner in academic use', BOOK 54p, p. V, 1-3, 6.

Paul, S. (2018) Diving Deep with Imbalanced Data. Available at: https://www.datacamp.com/community/tutorials/diving-deep-imbalanced-data (Accessed: 1 December 2018).

Purnamandari, N. P. Y. L. and Badera, I. D. N. (2015) 'Kemampuan Prediksi Rasio Keuangan dan Ukuran Bank Pada Risiko Gagal Bank', 4(6), pp. 1610-1623.

Saurkar, A. V et al. (2014) 'A Review Paper on Various Data Mining Techniques', International Journal of Advanced Research in Computer Science and Software Engineering, 4(4), pp. 2277128. doi: $10.4010 / 2016.1512$.

Widiharto, R. C. (2008) 'Analisis pengaruh rasio keuangan terhadap prediksi kondisi bermasalah bank perkreditan rakyat (Studi kepada Bank Perkreditan Rakyat di Wilayah Jakarta, Bogor, Depok, Tangerang dan Bekasi)'. 